\title{
Decentralized wastewater treatment performance evaluation based on chemical and physical parameters at Bantul Regency, Yogyakarta
}

\author{
Suphia Rahmawati $^{1,}{ }^{*}$, Andik Yulianto $^{1}$, and Ahmad Traju Pangentas Wijayaningrat ${ }^{1}$ \\ ${ }^{1}$ Environmental Engineering Study Program, Faculty of Civil Engineering and Planning, Universitas \\ Islam Indonesia, Indonesia.
}

\begin{abstract}
Communal wastewater treatment plant (CWWTP) has been chosen as one system to treat domestic wastewater due to simple technology, flexible management, and cost-effectiveness. There are 376 CWWTP have been recorded by Environmental Agency of Yogyakarta (DLH DIY) that spread in five regencies. Monitoring results on CWWTP effluent showed that some physical and chemical parameters did not meet the domestic wastewater standard. Therefore, evaluation of removal efficiency in terms physical and chemical parameters are necessary. The samples were collected from nine CWWTP in Banguntapan, Bantul and Gamping sub-districts. The physical and chemicals parameters ( $\mathrm{pH}, \mathrm{TSS}$, BOD, COD, Ammonia, oil, and grease) of influent and effluent from CWWTP are analyzed based on National Standard of Indonesia (SNI) for domestic wastewater. The results show that BOD $(>70 \%)$ and TSS $(>50 \%)$ have better removal effectiveness compare with COD, ammonia, oil, and grease (40\%). Overall, CWWTP in Banguntapan subdistrict has better performance compare with CWWTP in Bantul subdistrict.
\end{abstract}

\section{Introduction}

Domestic wastewater is wastewater that produced from various household activities such as from grey water (washing machines, shower, sinks), toilets (black water), etc [1]. To treat the domestic wastewater, the government proposes two types of wastewater management, on-site (septic tank and latrine) and off-site systems. However, until now, domestic wastewater management has not met the target. According to environment program of The United Nation in developing countries, around $90 \%$ of wastewater has been discharging untreated onto receiver waters [2]. It also reported that domestic wastewater has contributed $60 \%$ of pollution in natural receiving system [3]. According to The Ministry of Environment and Forestry of Indonesia (2015), 75.25\% of river water quality monitoring in 2013 was heavy polluted [4].

\footnotetext{
*Corresponding author: suphia.rahmawati@uii.ac.id
} 
Yogyakarta (DIY) as one of the provinces in Indonesia has a rapid development and population also face the domestic wastewater problems. According to The Environmental Agency of Yogyakarta (Dinas Lingkungan Hidup, DLH) domestic wastewater characteristic still not meet the standard for Biological Oxygen Demand (BOD) and Coliforms parameters [5]. Off-site wastewater system, Sewon, only cover 14,329 connections in 2012 from all the Yogyakarta coverage area [6]. Therefore the communal wastewater system become an alternative due to simple technology, flexible management, and cost-effectiveness [7, 8]. According to The Environmental Agency of Yogyakarta (DLH), communal wastewater treatment plant (CWWTP) has been increasing rapidly. In 2016, there are 376 CWWTP that spread in Sleman, Bantul, Kulon Progo, Gunung Kidul and Yogyakarta regency. Most of CWWTP are funding by Public Works of Yogyakarta Province (Dinas PUPM DIY) with the service coverage between 30 until 300 households. The common wastewater treatment technology that has been using is The Anaerobic Baffled Reactor (ABR).

ABR has been known since early 1980s [9], afterward it extensively use to treat wastewater due to numerous advantages such as: unaffected by shock loading both organic and hydraulic, can be constructed by local materials due to simple design, no electrical needed, greywater can managed simultaneously, odor and flies problems are minimum if used properly, highly reduce organics, relatively low-moderately cost depending on user number and maintenance [10]. However, the evaluation of ABR performance in Yogyakarta is still limited, especially for the early CWWTP. Base on DLH data, effluent quality monitoring is only limited to $41 \mathrm{CWWTP} \mathrm{[5].} \mathrm{In} \mathrm{addition,} \mathrm{monitoring} \mathrm{of} \mathrm{operational}$ and maintenance was held only in the beginning of CWWTP operation. Thus, some problems are arising in the existing CWWTP, such as an odor problem; the installation is damaged, clogging, etc. By looking the problems on the poor performance of CWWTP and its effect to the river water quality, it is necessary to conduct the evaluation of CWWTP performance in DIY base on chemical and physical parameter removal efficiency.

\section{Methods}

Sampling locations were selected from secondary data from Regional Environmental Agency of Yogyakarta (DLH) base on the coverage area (less than 100 households), the period of operational (less than 10 years), and monitoring data of CWWTP. There are nine CWWTPs were selected, four CWWTPs located in Banguntapan subdistrict namely Dokaran, Grojokan, Pamotan Lor, and Nglebeng; the other four CWWTPs located in Bantul subdistrict, namely, Manding Serut, Babadan I, II, and III. These eight of CWWTP are using Anaerobic Baffled Reactor (ABR) technology. While Sukunan CWWTP in Gamping subdistrict was selected which use Rotating Biological Contactors (RBC) as a comparison for treatment technology.

To determine the performance of CWWTP, physical and chemical parameters are selected base on domestic wastewater standard from Minister of Environment and Forestry decree (Permen LHK) No. 68, 2016 [11] and Regional Regulation of Yogyakarta (PERDA DIY) No.7 year 2016 [12], consist of parameters: pH, temperature, Biological Oxygen Demand (BOD), Chemical Oxygen Demand (COD), Total Suspended Solid (TSS), Dissolved Oxygen (DO), Total Suspended Solid (TSS), Total Dissolved Solids (TDS), ammonia, oil and grease. Observation and interview also conducted in order to collect the information about the CWWTP general condition including treatment technology, operational and maintenance.

Wastewater samples were collected between February until March 2018. The method of samples collection refers to Indonesia National Standard (SNI) No. 6989.59 (2008) part 59 about wastewater sampling method [13]. Samples were taken from the inlet and outlet of 
CWWTP in the morning, noon, and afternoon as composite samples. Temperature, $\mathrm{pH}$ and DO parameters are measured directly during sampling collection, while BOD, COD, TSS, ammonia, oil, and grease are determined at laboratory referring to SNI standard $[14,15]$ and Standard method for the examination of water and wastewater [16]. BOD was measured using the Winkler titration method. The close reflux method is used to determine COD using spectrophotometer while ammonia was obtained from the spectrophotometer method. In addition, TSS, TDS, oil, and grease are determined base on the gravimetric method,

The CWWTP performance was calculated from the removal of the physical and chemical parameter from influent and effluent of CWWTP using the Equation 1; a is represent parameter concentration in influent $(\mathrm{mg} / \mathrm{L})$ while $b$ is represent parameter concentration in effluent $(\mathrm{mg} / \mathrm{L})$.

$$
\text { Removal eficiency }=\frac{a-b}{a} * 100 \%
$$

\section{Result and Discussion}

\subsection{Characteristic of influent and effluent of CWWTP}

Table 1 shows the operational period, coverage area, and treatment technology of nine CWWTP in Banguntapan, Bantul, and Gamping subdistrict.

Table 1. The General condition of CWWTP

\begin{tabular}{|c|c|c|c|c|c|}
\hline No. & CWWTP & $\begin{array}{c}\text { Operational } \\
\text { (years) }\end{array}$ & $\begin{array}{c}\begin{array}{c}\text { Coverage } \\
\text { (households) }\end{array} \\
\end{array}$ & Technology & Treatment process \\
\hline \multicolumn{6}{|c|}{ Banguntapan subdistrict } \\
\hline 1 & Dokaran & 6 & 100 & $\mathrm{ABR}$ & 8 baffles \\
\hline 2 & Grojokan & 5 & 90 & $\mathrm{ABR}$ & 9 baffles \\
\hline 3 & Pamotan Lor & 6 & 70 & $\mathrm{ABR}$ & 5 baffles \\
\hline 4 & Nglebeng & 4 & 80 & $\mathrm{ABR}$ & 9 baffles \\
\hline \multicolumn{6}{|c|}{ Bantul subdistrict } \\
\hline 5 & Manding serut & 4 & 88 & $\mathrm{ABR}$ & 7 baffles \\
\hline \multirow[t]{2}{*}{6} & Babadan I & 6 & 100 & $\mathrm{ABR}$ & 8 baffles \\
\hline & Babadan II & 5 & 90 & $\mathrm{ABR}$ & 6 baffles \\
\hline 8 & Babadan III & 6 & 80 & $\mathrm{ABR}$ & 7 baffles \\
\hline \multicolumn{6}{|c|}{ Gamping subdistrict } \\
\hline 9 & Sukunan & 10 & 15 & $\mathrm{RBC}$ & $\begin{array}{l}\text { grit chamber }+ \text { screen } \rightarrow \\
\text { sedimentation I } \rightarrow \\
\text { Anaerobic Filter } \rightarrow \text { RBC } \rightarrow \\
\text { sedimentation II }\end{array}$ \\
\hline
\end{tabular}

Base on Table 1, all the CWWTP have an operational less than 10 years with coverage service are varied between 70 to 100 households. From the interviewed data, most of CWWTP are regularly monitored by DLH Yogyakarta 2-3 times a year except for Dokaran and Nglebeng CWWTP. All CWWTP in Banguntapan and Bantul subdistricts applied ABR technology with total baffle vary from 5 to 9 . On the other hand, Sukunan CWWTP applied RBC technology combine with anaerobic filtration. There are several problems occurs in CWWTP, such as clogging by oil and grease in Nglebeng, garbage problems in 
Pamotan Lor, sludge problem in Babadan II and III, and odor problem in Dokaran CWWTP.

Direct measurement of physical parameters for both influent and effluent in the sampling area shows that the $\mathrm{pH}$ has ranged between 6.0 to 8.3 , the temperature was varied from $25-31^{\circ} \mathrm{C}$, while DO has ranged from 0.6 to 3.6. The physical and chemical characteristic of influent and effluent each CWWTP are present in Table 2 and 3.

Table 2. The characteristic of CWWTP influent

\begin{tabular}{|c|c|c|c|c|c|c|c|c|}
\hline Subdistrict & No & CWWTP & $\begin{array}{l}\text { BOD } \\
(\mathrm{mg} / \mathrm{L})\end{array}$ & $\begin{array}{c}\text { COD } \\
(\mathrm{mg} / \mathrm{L})\end{array}$ & $\begin{array}{c}\mathrm{TSS} \\
(\mathrm{mg} / \mathrm{L})\end{array}$ & $\begin{array}{c}\text { Ammonia } \\
(\mathrm{mg} / \mathrm{L})\end{array}$ & $\begin{array}{l}\text { Oil and grease } \\
(\mathrm{mg} / \mathrm{L})\end{array}$ & $\mathrm{pH}$ \\
\hline \multirow{4}{*}{ Banguntapan } & 1 & Dokaran & 484 & 154 & 672 & 38 & 197 & 7 \\
\hline & 2 & Grojogan & 282 & 353 & $1205^{*}$ & $40 *$ & $606^{*}$ & 7 \\
\hline & 3 & Pamotan Lor & $968 *$ & 410 & 323 & 12 & 130 & 7 \\
\hline & 4 & Nglebeng & 484 & 235 & 273 & 10 & 86 & 7 \\
\hline \multirow{4}{*}{ Bantul } & 5 & Manding Serut & 726 & 399 & 107 & 0 & 138 & 6 \\
\hline & 6 & Babadan I & 806 & 398 & 267 & 0 & 155 & 7 \\
\hline & 7 & Babadan II & 121 & 270 & 422 & 26 & 96 & 7 \\
\hline & 8 & Babadan III & 161 & 461 & 637 & 24 & 54 & 7 \\
\hline Gamping & & Sukunan & 202 & $500 *$ & 80 & 4 & 4 & 7 \\
\hline
\end{tabular}

*The highest concentration

Table 3. The characteristic of CWWTP effluent

\begin{tabular}{|c|c|c|c|c|c|c|c|c|}
\hline Subdistrict & No & CWWTP & $\begin{array}{l}\mathrm{BOD} \\
(\mathrm{mg} / \mathrm{L})\end{array}$ & $\begin{array}{l}\text { COD } \\
(\mathrm{mg} / \mathrm{L})\end{array}$ & $\begin{array}{c}\text { TSS } \\
(\mathrm{mg} / \mathrm{L})\end{array}$ & $\begin{array}{c}\text { Ammonia } \\
(\mathrm{mg} / \mathrm{L})\end{array}$ & $\begin{array}{l}\text { Oil and } \\
\text { grease } \\
(\mathrm{mg} / \mathrm{L})\end{array}$ & $\mathrm{pH}$ \\
\hline \multirow{4}{*}{ Banguntapan } & 1 & Dokaran & 69 & 144 & 483 & 37 & 39 & 7 \\
\hline & 2 & Grojogan & 56 & 123 & 303 & 38 & 177 & 7 \\
\hline & 3 & Pamotan Lor & 85 & 223 & 185 & 11 & 91 & 7 \\
\hline & 4 & Nglebeng & 16 & 168 & 115 & 7 & 14 & 7 \\
\hline \multirow{4}{*}{ Bantul } & 5 & Manding Serut & 12 & 308 & 73 & 0 & 127 & 6 \\
\hline & 6 & Babadan I & 28 & 260 & 160 & 0 & 130 & 7 \\
\hline & 7 & Babadan II & 93 & 248 & 188 & 23 & 40 & 7 \\
\hline & 8 & Babadan III & 105 & 375 & 215 & 23 & 37 & 7 \\
\hline Gamping & & IPAL Sukunan & 93 & 331 & 17 & 3 & 1 & 7 \\
\hline \multicolumn{3}{|c|}{ Regional Regulation of DIY No.7, 2016} & 75 & 200 & 75 & - & 10 & $6-9$ \\
\hline \multicolumn{3}{|c|}{$\begin{array}{l}\text { Minister of Environment and Forestry } \\
\text { decree No. } 68,2016\end{array}$} & 30 & 100 & 30 & 5 & 10 & $6-9$ \\
\hline
\end{tabular}

According to Table 2, BOD concentration is varied from 121-968 mg/L and the highest concentration found at Pamotan Lor CWWTP. On the other hand, the highest concentration of COD was found at Sukunan CWWTP. Furthermore, the highest concentration of ammonia, TSS, oil, and grease are found at Grojokan CWWTP. Physical parameters, $\mathrm{pH}$, was between 6 and 7. According to Metcalf and Eddy (2002), the characteristic of BOD concentration is categorized as a medium to high strength (190 to $350 \mathrm{mg} / \mathrm{L}$ and $>350 \mathrm{mg} / \mathrm{L}$ ) except for Babadan I and II, whereas COD concentration is categorized as low to medium strength. The category of Ammonia, TSS, oil, and grease are varying from low, medium and high strength. The variety of influent characteristics is influenced by several factors such as the flow rate and the household activities. The quantity of organic pollutant and the carbon source from detergents affected the COD values [17]. In addition, 25-35\% of total COD comes from fat, oil, and grease. In case domestic wastewater, fat, oil, and grease produce from the food processing and kitchen activities [18].

Table 3 shows the concentration of effluent from CWWTP and the comparison with the domestic wastewater standards. More than $56 \%$ samples of all parameters are above the wastewater standard according to Minister of Environment and Forestry [11] and Regional Regulation of Yogyakarta [12] except for $\mathrm{pH}$, il and grease concentration in all CWWTP with ABR technology have exceeded both standards. Pamotan Lor, Babadan II, and 
Babadan III CWWTP have poor effluent quality compared with the others CWWTP. All parameters, BOD, COD, TSS, ammonia, oil and grease are exceeding the standards. Similar results also showed by Septyani et. al (2016) studies in Rusunawa Tanah Merah II wastewater treatment plant which are parameters of BOD, COD, TSS, oil, and grease above the standard [19].

Previous studies on anaerobic process of wastewater treatment showed that quality of effluent water depends on several factors such as: the characteristics, composition, and flowrate of influent water; biomass activity and its contact with organic matter; hydraulic retention time (HRT). These factors cause some main advantages for example: BOD, COD, nitrogen and phosphorus remain high after the process, slow recovery from a toxic loading, sensitive to ambient temperature, and the limitation of full-scale treatment of design and maintenance $[20,21]$. This study shows that the characteristics of most of the influent waters are categorized as medium to high strength. In addition, according to the interview data, CWWTPs were design mostly base on the influent flow rate but not the loading rate therefore the treatment will not optimum. Desludging was infrequent and only at the end of ABR compartment unit. Poor maintenance of sludge can reduce the volume of ABR system and interfere the biomass activities. Therefore post-treatment is needed in order to meet the discharge standards if the effluent will discharge to surface water [22]

\subsection{The Removal Efficiency and Effectiveness of CWWTP}

Efficiency removals of physical and chemical parameters are determined from inlet and outlet concentration (Figure 1).

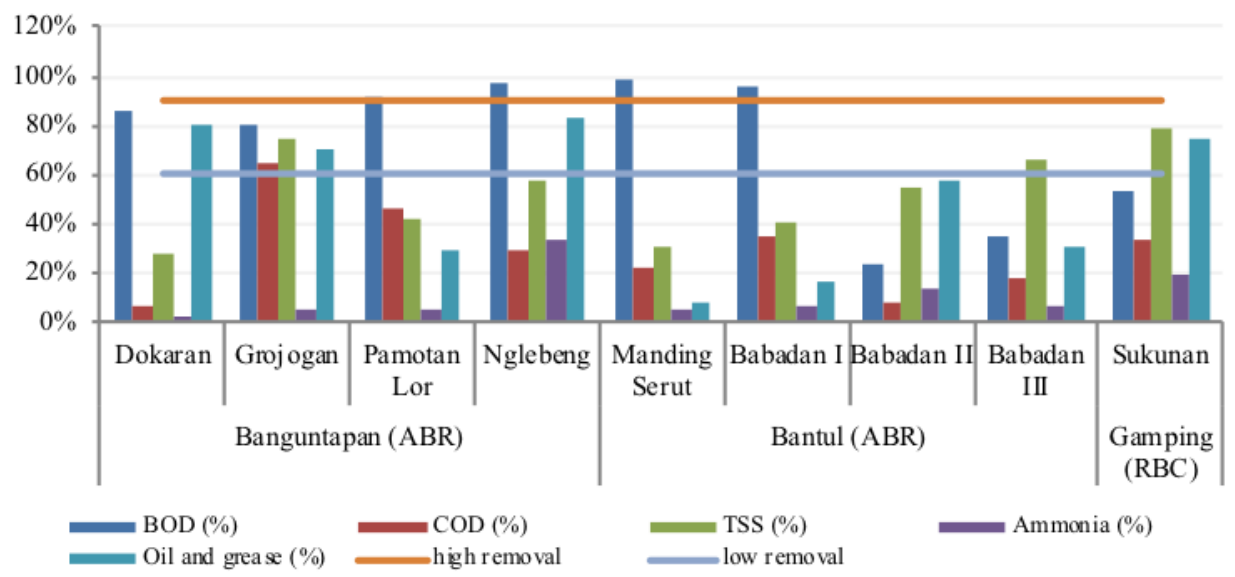

Fig. 1. Physical and chemical parameters removal of CWWTP

Figure 1 shows that BOD removal mostly above $80 \%$ except for Babadan II (23\%) and III (35\%) CWWTP. For COD, oil and grease parameters, 50\% of CWWTP have efficiency removal above $50 \%$. The lower percentage removal of COD was found in Dokaran $(7 \%)$ dan Babadan II (8\%), whereas the lowest removal of oil and grease parameter was found in Manding serut. Ammonia removal for all CWWTP is less than $35 \%$ with the highest percentage is found in Nglebeng (34\%) and the lowest is Dokaran CWWTP (3\%). A similar tendency also found at Sukunan CWWTP, the highest removal is found in TSS parameter while the lowest removal is found in ammonia parameter. The effectiveness of CWWTP is determined from the average of the percentage of all removal parameters that can be shown in Figure 2. 


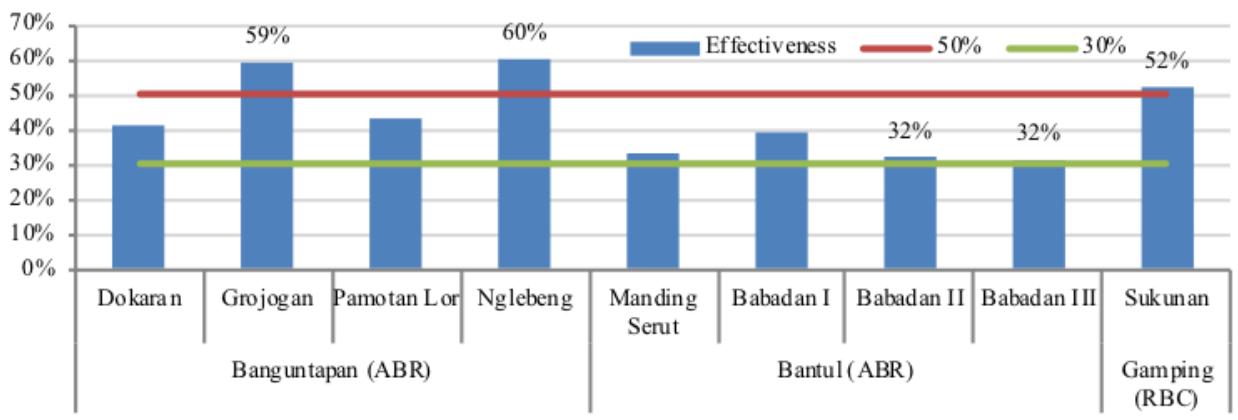

Fig. 2. The effectiveness of CWWTP

It can be seen from Figure 2, only two CWWTPs with ABR technology have the effectiveness of more than $50 \%$ while the others vary from $32 \%$ to $43 \%$. Sukunan CWWTP with RBC technology has $52 \%$ effectiveness. Generally, ABR technology has known to reduce BOD 70-95\% [8], and reduce COD and solids [18], however, some conditions could decrease its effectiveness. The presence of fat, oil, and grease could affect the efficiency of the wastewater treatment plant in an anaerobic and aerobic process, also the decreasing the wastewater effluent quality due to the increase of organic material [23].

Evaluations of removal capacity of CWWTP are also conducted by comparing existing BOD and COD parameters removal with design removal capacity. The design removal capacity was calculated based on the coverage service (number of households), wastewater flow rate (120L/households/day) and the total number of baffle. The comparison shows in Figure 3.
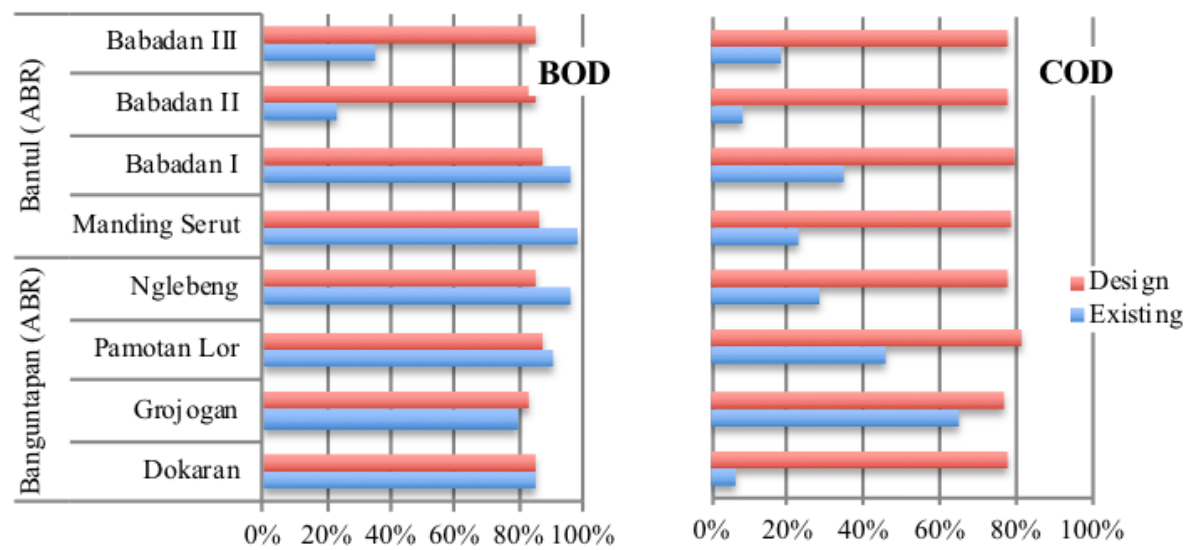

Fig. 3. Comparison of removal effectiveness of BOD and COD between design capacity and existing

The comparison shows that existing BOD removal with the design capacity almost similar except for Babadan II and III. On the other hand, COD parameters, the existing removal far below the design removal capacity. To increase the capacity of COD removals, some modifications could be proposed for example: (1) increase the HRT of process, according to Nasr et al. (2009) studies, COD concentration corresponding with the decrease of HRT [24], similar results also showed by Dama et al (2002) [18]; (2) post-treatment may be needed to remove the residual of TSS and COD, since anaerobic process efficient to remove organic material and suspended solid [24]; (3) combination between anaerobic 
process $(\mathrm{ABR})$ and aerobic process could enhance the removal effectiveness [24]; poor maintenance suggest sludge accumulation and decrease treatment volume [19].

\section{Conclusion}

The results show that removal efficiency is relatively high for BOD ( $>76 \%$ in average) and TSS $(>50 \%$ in average) parameters in Banguntapan and Bantul subdistricts. However, COD, ammonia, oil, and grease the removal efficiency are low (less than $40 \%$ ). The performance or the removal efficiency of CWWTP in Banguntapan (51\% in average) is more sufficient than CWWTP in Bantul (34\% on average). Comparison of CWWTP performance between CWWTP with ABR system with RBC system in Sukunan CWWTP did not show significant differences. In order to enhance the performance of CWWTP, there are several ways that could be offered, for example: regularly monitoring, proper maintenance, standard of operational and maintenance (SOP), the addition unit like grease trap to minimize the oil and grease concentration, and increase the HRT of the treatment unit.

\section{References}

1. Asian Development Bank. Urban Wastewater Management in Indonesia. Key Principles and Issue in Drafting Local Regulations. Manila. (2017)

2. UNEP, UN-Habitat. Norway: GRID-Arendal (2010)

3. Directorate General of Water Resources Ministry of Public Works, United Nations Environment Programme (UNEP), Indonesia Water Partnership. Workshop on Integrated Water Resources Management Functions In term of Environmental Sustainability Aspect. (2006)

4. N. I. Said. Seminar INCHEM Tokyo. (2017) www.unido.or.jp/files/Indonesiasmall.pdf accessed on August 19, 2018

5. Badan Lingkungan Hidup DIY, 2018

6. D. Kumalasari. S1 thesis, Fakultas Ilmu Sosial. Universitas Negeri Yogyakarta. (2014) http://eprints.uny.ac.id/18316/ accessed on August 19, 2018

7. D. Hendrawan, S. Widarnako, S.S. Moersidik, R.W. Triweko. European Sci J. 9. 17(2013)

8. Tim Teknis Pembangunan Sanitasi (TTPS). Buku Referensi. (2010)

9. S. R. Hassan, I. Dahlan Cent. Eur. J. Eng. 3(3), 389-399 (2013)

10. Water and Sanitation Program - East Asia and the Pacific. Philippines sanitation source book and decision aid. (2005)

11. Kementrian Lingkungan Hidup dan Kehutanan Republik Indonesia. Peraturan Menteri Lingkungan Hidup dan Kehutanan Republik Indonesia (Permen LHK) Nomor. P.68/Menlhk/Setjen/Kum.1/8/2016. (2016)

12. Gubernur Daerah Istimewa Yogyakarta Peraturan Daerah Daerah Istimewa Yogyakarta Nomor 7 Tahun 2016 . (2016)

13. National Standardization Agency of Indonesia. Indonesian Standard No. SNI 6989.592008. (2008)

14. National Standardization Agency of Indonesia. Indonesian Standard No. SNI 066989.23-2005. (2005) 
15. National Standardization Agency of Indonesia. Indonesian Standard No. SNI 066989.11-2004. (2004)

16. Standard Methods for the Examination of Water and Wastewater. 21st Edition. 4500O G. 2005

17. V.S. Ghorpade, and P.G. Sonawane. LIETR. 3-12, 47-49 (2015)

18. P. Dama, J. Bell, K.M. Foxon, C.J. Brouckaert, T. Huang, C.A. Buckley, V. Naidoo and D. Stuckey. Wat Sci Tech. Article. (2002)

19. E. S. H. Saputri, D. Bambang S. Undergraduate Thesis. Institut Teknologi Sepuluh November (2016)

20. K. Mergaert, B. Vanderhaegen, W. Verstraete. War. Res. 26, 1025-1033 (1992)

21. G. Lellinga, A.D. Man, A.R.M. ver der Last, W. Wiegant, K. van Knippenberg, J. Fnjins, J.C.L. van Buuren. War. Sci. Technol. 27 (9), 67-73 (1993)

22. H. Yu, J.H. Tay, F. Wilson. Wat. Sci. Tech. 35(9), 191-198 (1997)

23. M. Dehghani, H. Sadatjo, H. Maleknia, N. Shamsedini. J Health Res. 5, 6 (2014)

24. F.A. Nasr, H.S. Doma, H.F. Nassar. Environmentalist. 29, 270-279. (2009) 